\title{
Clinical parameters associated with obesity outcomes in vulnerable adolescents
}

\author{
Parâmetros clínicos associados aos desfechos de obesidade em adolescentes vullneráveis \\ Parámetros clínicos asociados con los resultados de la obesidad en adolescentes vulnerables
}

Received: 04/08/2021 | Reviewed: 04/13/2021 | Accept: 04/14/2021 | Published: 05/04/2021

\author{
Gleyce Angélica Ribeiro \\ ORCID: https://orcid.org/0000-0001-5300-314X \\ Centro Universitário da Fundação Hermínio Ometto, Brazil \\ E-mail: gleycerib@hotmail.com \\ Diego Patrik Alves Carneiro \\ ORCID: https://orcid.org/0000-0001-7864-3055 \\ Universidade Estadual de Campinas, Brazil \\ E-mail: diegocarneiromoa@gmail.com \\ Giovana Cherubini Venezian \\ ORCID: https://orcid.org/0000-0003-4643-7964 \\ Centro Universitário da Fundação Hermínio Ometto, Brazil \\ E-mail: giovanavenezian@fho.edu.br \\ Carolina Carmo de Menezes \\ ORCID: https://orcid.org/0000-0002-8875-8611 \\ Centro Universitário da Fundação Hermínio Ometto, Brazil \\ E-mail: carolinamenezes@fho.edu.br \\ Silvia Amélia Scudeler Vedovello \\ ORCID: https://orcid.org/0000-00002-7203-2867 \\ Centro Universitário da Fundação Hermínio Ometto, Brazil \\ E-mail: silviavedovello@gmail.com \\ Viviane Veroni Degan \\ ORCID: https://orcid.org/0000-0001-9043-8265 \\ Centro Universitário da Fundação Hermínio Ometto, Brazil \\ E-mail: vivianedegan @ fho.edu.br
}

\begin{abstract}
Objective: Overweight and obesity rates are growing at alarming levels worldwide. Adolescents of higher socioeconomic status are more likely to be overweight, however, information from economically vulnerable populations is lacking. Therefore, the present study aimed to determine the impact of normative and self-perceived clinical aspects on the outcomes of obesity in vulnerable adolescents. Methodology: Observational cross-sectional study with 239 adolescents with an average age of 13 years, enrolled in public schools in Sabará (Minas Gerais). Body Mass Index values were obtained and classified according to AnthroPlus software. Dental Health Component of the Index of Orthodontic Treatment Need (IOTN) evaluated the normative malocclusion and the Aesthetic Component of IOTN the subjective occlusal evaluation. DMFT index evaluated dental caries activity and experience. Crude Odds Ratio values were estimated and adjusted, with a 95\% confidence interval and a 5\% significance level. Results: Adolescents with self-perceived malocclusion were less likely to be obese $(P<0.05)$. Overall, $20.0 \%$ of the adolescents with self-perceived malocclusion were obese as compared to $40.6 \%$ of those with no self-perceived malocclusion. Obesity was not found to be associated with the variables of sex and dental caries $(P>0.05)$. Conclusion: Adolescents with self-perceived malocclusion were less likely to be obese, suggesting that obesity is associated with perceived malocclusion, but not with caries experience.
\end{abstract}

Keywords: Obesity; Adolescents; Malocclusion; Orthodontics.

\section{Resumo}

Objetivo: As taxas de sobrepeso e obesidade estão crescendo em níveis alarmantes em todo o mundo. Adolescentes de nível socioeconômico mais elevado têm maior probabilidade de apresentar excesso de peso, no entanto, faltam informações de populações economicamente vulneráveis. Metodologia: Portanto, o presente estudo teve como objetivo determinar o impacto de aspectos clínicos normativos e autopercebidos nos desfechos da obesidade em adolescentes vulneráveis. Estudo transversal observacional realizado com 239 adolescentes com idade média de 13 anos, matriculados nas escolas públicas de Sabará (Minas Gerais). Os valores do Índice de Massa Corporal foram obtidos e classificados de acordo com o software AnthroPlus. O Componente de Saúde Bucal do Índice de Necessidade de Tratamento Ortodôntico (IOTN) avaliou a má oclusão normativa e o Componente Estético do IOTN a avaliação oclusal subjetiva. O índice CPO-D avaliou a atividade e a experiência de cárie dentária. Os valores de Odds Ratio foram estimados e ajustados, com intervalo de confiança de 95\% e nível de significância de 5\%. Resultados: Adolescentes com má oclusão percebida eram menos propensos a serem obesos $(P<0.05)$. No geral, $20.0 \%$ dos 
adolescentes com má oclusão percebida eram obesos, em comparação com $40.6 \%$ daqueles sem má oclusão percebida. A obesidade não foi associada às variáveis sexo e cárie dentária $(P>0.05)$. Conclusão: Adolescentes com má oclusão autopercebida eram menos propensos a serem obesos, sugerindo que a obesidade está associada à má oclusão percebida, mas não à experiência de cárie.

Palavras-chave: Obesidade; Adolescente; Má oclusão; Ortodontia.

\section{Resumen}

Objetivo: Las tasas de sobrepeso y obesidad están aumentando a niveles alarmantes en todo el mundo. Los adolescentes de nivel socioeconómico más alto tienen más probabilidades de tener sobrepeso, sin embargo, se carece de información de poblaciones económicamente vulnerables. Metodologia: Por lo tanto, el presente estudio tuvo como objetivo determinar el impacto de los aspectos clínicos normativos y autopercibidos sobre los resultados de la obesidad en adolescentes vulnerables. Estudio observacional transversal realizado con 239 adolescentes con una edad promedio de 13 años, matriculados en escuelas públicas de Sabará (Minas Gerais). Los valores del Índice de Masa Corporal se obtuvieron y clasificaron según el software AnthroPlus. El componente de salud bucal del índice de necesidades de tratamiento de ortodoncia (IOTN) evaluó la maloclusión normativa y el componente estético de la IOTN evaluó la evaluación oclusal subjetiva. El índice CPO-D evaluó la actividad y la experiencia de la caries dental. Se estimaron y ajustaron los valores de Odds Ratio, con un intervalo de confianza del $95 \%$ y un nivel de significancia del 5\%. Resultados: Los adolescentes con maloclusión percibida tenían menos probabilidades de ser obesos $(P<$ 0.05). En general, el $20.0 \%$ de los adolescentes con maloclusión percibida eran obesos, en comparación con el $40.6 \%$ de aquellos sin maloclusión percibida. La obesidad no se asoció con el género y la caries dental $(P>0.05)$. Conclusión: Los adolescentes con maloclusión autopercibida tenían menos probabilidades de ser obesos, lo que sugiere que la obesidad está asociada con la maloclusión percibida, pero no con la experiencia de caries.

Palabras clave: Obesidad; Adolescentes; Maloclusión; Ortodoncia.

\section{Introduction}

Obesity is a chronic multifactorial disease, highly prevalent worldwide (Rando-Meireles et al. 2019). Due to its broad distribution and severe health consequences, obesity remains one of the significant health burdens to the public healthcare system (Markovic et al. 2015). Although it is historically more prevalent in developed countries, particularly among individuals with low education and low income, obesity prevalence rates have started to increase in the same way in underdeveloped countries (Markovic et al. 2015, Abbass et al. 2019). Bad eating habits and a sedentary lifestyle are associated with obesity (Markovic et al. 2015, Abbass et al. 2019).

Obesity can also be associated with dental caries, as both conditions result from high sugar consumption behavior, severely affecting the individual's systemic condition (Rando-Meireles et al. 2019, Abbass et al. 2019, Gautam \& Jeong, 2019). The association between obesity and dental caries outcomes has been a topic of study in recent years (Lara-Capi et al. 2018, Shivakumar et al. 2018, Gautam \& Jeong, 2019). Some authors suggest that changes in eating habits concerning a more inadequate diet can favor the onset of oral diseases (Lara-Capi et al. 2018, Shivakumar et al. 2018, Banu et al., 2018). However, no conclusive evidence has been reported so far (Markovic et al. 2015, Abbass et al. 2019). The inconsistency of the data may be the result of variations in the design and methods of the study, especially about dental caries assessment tools. Some indices assessing caries lesions in early stages may overestimate the prevalence of the disease, while others consider only cavitated dentin lesions (Lara-Capi et al. 2018, Banu et al. 2018). Moreover, inter-study comparison may prove a challenging task due to the presence of confounding factors that are not commonly controlled, including socioeconomic characteristics, dietary habits, oral hygiene practice, and oral care provided by healthcare services (Shivakumar et al. 2018).

In this sense, malocclusion can also be associated with obesity. Both malocclusion and obesity influence dissatisfaction with body image in children and adolescents (Banu et al. 2018), resulting in psychological conditions such as low self-esteem, dissatisfaction with the quality of life, obsessive-compulsive behavior, anxiety and depression (Banu et al. 2018; Sagar \& Gupta 2018, Blanco et al. 2019). To the best of our knowledge, there is no evidence on the association of selfperception malocclusion and obesity in groups of vulnerable adolescents. Mainly how much the self-perceived malocclusion is associated with obesity. 
Therefore, this study aimed to associate the impact of normative and self-perceived clinical aspects on obesity outcomes in vulnerable Brazilian adolescents. The hypothesis was that obesity outcomes are significantly associated with dental caries and malocclusion in an economically vulnerable adolescent population.

\section{Methodology}

This study was approved by the Ethics Committee (\#77223317.9.0000.5385) and performed according to the STROBE statement. Adolescents and their legal guardians were informed that participation in the study was entirely voluntary. Legal guardians and adolescents signed a free statement of informed consent term. The participants were informed about the study objectives and the confidentiality of the data.

A population-based cross-sectional study was conducted involving adolescents enrolled in public schools distributed throughout every neighborhood of the city of Sabará (Minas Gerais), Southeast Brazil. The city had an estimated population of 136,344 inhabitants at the time of data collection, and a human development index of 0.73 (Atlas of Human Development in Brazil).

The sample size was calculated in the $G^{*}$ Power Program, considering a proportion of obese individuals of approximately 8\%, according to the Study of Cardiovascular Risks in Adolescents (Lavrador et al. 2010) a significance level of $5 \%$ and a test power of $80 \%$. In addition, the sample size was enlarged by $30 \%$ (to 239 adolescents) to account for nonresponse.

The study included adolescents living in rural areas, with an average monthly family income of US $\$ 250.00$ and parents with low education. A questionnaire was sent to parents, together with the informed consent form, to select vulnerable adolescents. The exclusion criteria were a history of previous or current orthodontic treatment, and an apparent mental and physical disability that made the interview or oral examination impossible. The final sample consisted of 239 adolescents, 138 girls, and 101 boys, with an average age of 13.4 years (Figure 1). Data collection was performed between February to April 2019. Interviews and dental examinations were carried out on the adolescents at school.

Figure 1. Flowchart of eligibility and recruitment of study participants.

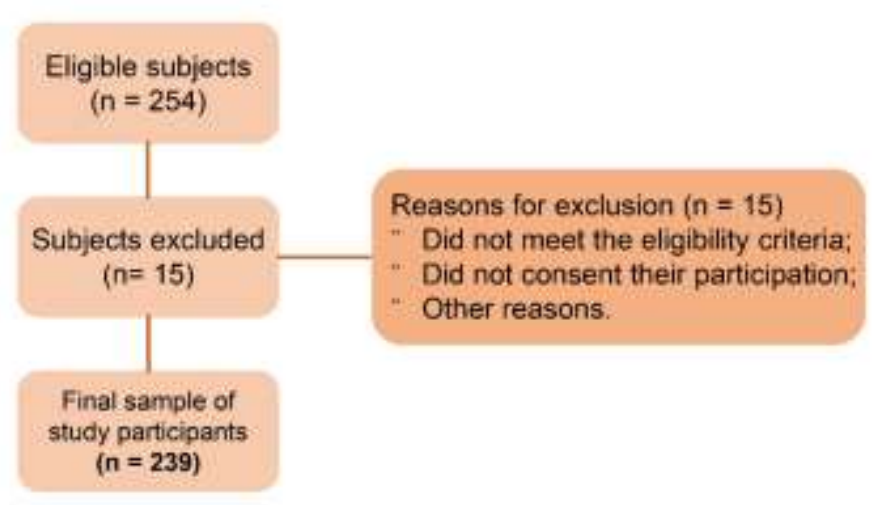

Source: Authors (2021).

Body Mass Index (BMI) values were obtained and used for the classification of obesity. The AnthroPlus anthropometric calculator (World Health Organization, 2009), developed by the World Health Organization (WHO), processed data on weight, height, sex, and age. The individual's weight in kilograms divided by the square of his height in meters (Kg / $\mathrm{m}^{2}$ ) determined the BMI values. BMI percentiles were obtained and presented as one decimal place for the number of standard 
deviations (SD) of the median or as two decimal places for the median, which is also known as the "z-score." Percentile values $\leq 85$ were indicative of eutrophy (normal weight) (z-score $\geq-1$ and $\leq+1$ ); percentile values between 85 and 97 were classified as overweight ( $\mathrm{z}$-score $\geq+1$ and $<+2$ ); percentile values between 97 and 99.9 were classified as obesity $(\mathrm{z}$-score $\geq+2$ and $\leq$ +3) whereas values above 99.9 were indicative of severe obesity (z-score > + 3) (Figure 2). Study participants were classified according to the WHO criteria and dichotomized into eutrophic (normal weight) or obese (overweight, obese, and severely obese) (Consolação Soares et al. 2017) (Figure 2).

Figure 2. Body Mass Index (BMI) classification.

\begin{tabular}{|c|c|c|}
\hline \multicolumn{2}{|c|}{ Body Mass Index (BMI) } & \multirow{2}{*}{$\begin{array}{c}\text { Nutritional } \\
\text { diagnosis }\end{array}$} \\
\hline Percentile & $z$-score & Eutrophy \\
\hline $\begin{array}{c}\leq 85 \text { th percentile } \\
\begin{array}{c}>85 \text { th percentile and }<97 \text { th } \\
\text { percentile }\end{array}\end{array}$ & $z$-score $\geq-1$ and $\leq+1$ & Overweight \\
\hline $\begin{array}{c}\geq 97 \text { th percentile and } \leq 99.9 \text { th } \\
\text { percentile }\end{array}$ & $z$ z-score $\geq+2$ and $<+2$ & Obesity \\
\hline$>99.9$ th percentile & z-score $>+3$ & Severe obesity \\
\hline
\end{tabular}

Source: World Health Organization (2009).

The Dental Health Component (DHC) of the Orthodontic Treatment Needs Index (IOTN) assessed normative malocclusion (Brook \& Shaw 1989). All occlusal alterations were recorded, and only the most severe one served for the classification of the individual's need for treatment (Brook \& Shaw 1989). The following occlusal conditions were considered: missing teeth, including congenital tooth absence and impacted teeth; overjet (positive or negative); crossbite; displacements of contact points; overbite and open bite (Brook \& Shaw 1989). Adolescents were classified according to their need for orthodontic treatment into grades 1 and 2 (no need or little need), grade 3 (moderate need), or grade 4 and 5 (great need). The data were dichotomized into "no normative malocclusion" (grades 1 and 2) or "normative malocclusion" (grades 3 to 5 ) (Brook \& Shaw 1989).

The IOTN Aesthetic Component (AC) evaluated subjective malocclusion. The IOTN-AC considers the individual's psychosocial needs based on a Dental Attractiveness Scale (DAS), with ten color photographs with a decreasing degree of attractiveness, that is, the first photograph shows the most attractive occlusion pattern whereas the tenth shows the least attractive one. The IOTN-AC was self-rated by participating adolescents based on the similarity of their occlusion with the patterns contained in the DAS. Photographs \#1 to \#4 corresponding to individuals with little or no need for orthodontic treatment (grade 1 and 2); photographs \#5, \#6 and \#7 indicated a moderate need for orthodontic treatment (grade 3), whereas photographs \#8, \#9 and \#10 indicated a severe need for orthodontic treatment (grade 4 and 5) (Brook \& Shaw 1989). For data analysis, the IOTN-AC was dichotomized into "no self-perceived malocclusion" (grades 1 and 2) or "self-perceived malocclusion" (grades 3, 4, and 5).

The DMFT index was used to evaluate dental caries activity and / or experience, according to the WHO criteria (WHO, 1997). For data analysis, all maxillary and mandibular teeth were considered, and adolescents with DMFT $=0$ were classified as having no caries activity/experience while those with DMFT $\geq 1$ were classified as having caries activity/experience.

The clinical examination were performed by one calibrated dentist, who participated in theoretical training exercises and clinical calibration based on criteria proposed by the IOTN-DHC (malocclusion) and DMFT-index (dental caries). The 
inter-examiner Kappa coefficient was higher than 0.91 and 0.98 for the evaluation of malocclusion, and dental caries, respectively. To check for intra-examiner reproducibility, approximately $10 \%$ of the sample was re-examined.

Individual analyses were performed using obesity as outcome and the independent variables (self-perceived malocclusion-IOTN-AC, normative malocclusion-IOTN-DHC, and caries activity/experience-DMFT). The raw odds ratio (OR) was estimated with a CI of 95\%. The variables with $P<0.20$ in the individual analyses were tested in the multiple logistic regression models, and those with $P \leq 0.05$ remained in the model, with the adjusted OR estimated with a CI of $95 \%$. Analyses were performed in the $\mathrm{R}$ program ( $\mathrm{R}$ Foundation for Statistical Computing, Vienna, Austria), considering a 5\% significance.

\section{Results}

The mean age of the sample was 13.4 years, with a standard deviation of 1.61 , a median of 13 years, a minimum of 10 years, and a maximum of 17 years; $57.7 \%$ of the sample were females, and $42.3 \%$ were males. Our findings showed an $8.4 \%$ prevalence of self-perceived malocclusion, as compared to $94.6 \%$ prevalence of normative malocclusion based on orthodontist's clinical examination. The prevalence rates of obesity and caries activity/experience in the study sample were $38.9 \%$ and $49.4 \%$, respectively. Table 1 summarizes the distribution of variables.

Table 1. Absolute frequency of the study variables.

\begin{tabular}{lll}
\hline \multirow{2}{*}{ Sex } & Female & $138(57.7 \%)$ \\
& Male & $101(42.3 \%)$ \\
\hline \multirow{2}{*}{ Obesity } & Absent & $146(61.1 \%)$ \\
& Present & $93(38.9 \%)$ \\
\hline $\begin{array}{l}\text { Self-perceived malocclusion } \\
\text { (IOTN-AC) }\end{array}$ & Absent & $219(91.6 \%)$ \\
\hline $\begin{array}{l}\text { Normative malocclusion } \\
\text { (IOTN-DHC) }\end{array}$ & Present & $20(8.4 \%)$ \\
\hline \multirow{2}{*}{ Caries activity / experience } & Present & $13(5.4 \%)$ \\
& Pbsent & $226(94.6 \%)$ \\
\hline
\end{tabular}

Source: Authors (2021).

Table 2 shows the association between the study variables and obesity outcomes in study participants. Considering the adjusted analysis (adjusted OR), adolescents with self-perceived malocclusion presented a $(P<0.05 ; \mathrm{OR}=0.31,95 \% \mathrm{CI}$ : 0.10-0.99) higher likelihood of not being obese. Twenty percent of the adolescents with self-perceived malocclusion were obese, as compared to $40.6 \%$ of those with no self-perceived malocclusion. The variables of sex, normative malocclusion, and caries activity/experience were not associated with obesity $(P>0.05)$. 
Table 2. Association between the study variables and obesity outcomes in economically vulnerable adolescents.

\begin{tabular}{|c|c|c|c|c|c|c|c|}
\hline \multirow[t]{2}{*}{ Variable } & \multirow[t]{2}{*}{ Category } & \multicolumn{2}{|c|}{ Obesity } & \multirow{2}{*}{$\begin{array}{l}{ }^{\$} \text { Crude OR } \\
\left({ }^{\# 95 \%} \mathrm{CI}\right)\end{array}$} & \multirow[t]{2}{*}{$P$-value } & \multirow{2}{*}{${ }^{\$}$ Adjusted OR $\left({ }^{\# 95 \% ~ C I) ~}\right.$} & \multirow[t]{2}{*}{$P$-value } \\
\hline & & Absent & *Present & & & & \\
\hline \multirow[t]{2}{*}{ Sex } & Female & $78(56.5 \%)$ & $60(43.5 \%)$ & $1.58(0.93-2.71)$ & 0.0915 & & \\
\hline & Male & $68(67.3 \%)$ & $33(32.7 \%)$ & 1 & & & \\
\hline \multirow{2}{*}{$\begin{array}{l}\text { Self-perceived malocclusion } \\
\text { (IOTN-AC) }\end{array}$} & Absent & $130(59.4 \%)$ & $89(40.6 \%)$ & 1 & & 1 & \\
\hline & Present & $16(80.0 \%)$ & $4(20.0 \%)$ & $0.36(0.12-1.13)$ & 0.0801 & $0.31(0.10-0.99)$ & 0.0472 \\
\hline \multirow{2}{*}{$\begin{array}{l}\text { Normative malocclusion (IOTN- } \\
\text { DHC) }\end{array}$} & Absent & $7(53.8 \%)$ & $6(46.2 \%)$ & 1 & & & \\
\hline & Present & $139(61.5 \%)$ & $87(38.5 \%)$ & $0.73(0.24-2.24)$ & 0.5831 & & \\
\hline \multirow{2}{*}{$\begin{array}{l}\text { Caries activity / experience } \\
(\mathrm{DMFT})\end{array}$} & Absent & $69(57.0 \%)$ & $52(43.0 \%)$ & 1 & & & \\
\hline & Present & $77(65.3 \%)$ & $41(34.7 \%)$ & $0.71(0.42-1.19)$ & 0.1927 & & \\
\hline
\end{tabular}

${ }^{*}$ Reference category for the outcome variable; ${ }^{\$}$ Odds ratio; ${ }^{\sharp}$ Confidence interval. 


\section{Discussion}

The prevalence rates of overweight and obesity in adolescents reached very high levels (Jones Bell et al. 2018). According to the WHO, these figures have tripled in the last four decades and ranked obesity as one of the significant healthrelated challenges worldwide (Shivakumar et al. 2018). Hence, studies on overweight-associated factors are needed to understand the effects of obesity on the adolescent's life and to implement effective public policies aimed at controlling the condition in this population. In our study, the prevalence of obesity in adolescents was 38.9\%, which was higher than that reported in Saudi Arabia (13.4\%), India (17.0\%) and China (9.6\%) (Zhou et al. 2017, Gautam \& Jeong 2018, Al-Hassaini et al. 2019).

The literature highlights that individuals with higher socioeconomic status are more likely to be overweight (Gautam \& Jeong 2018, Al-Hassaini et al. 2019). However, low- and middle-income countries also show high rates of obesity (Ashdown-Franks et al. 2019). What justifies studying the results of obesity in economically vulnerable adolescents in Brazil. A recent study determined the prevalence rates of obesity in adolescents in 58 countries worldwide. Central and South America showed the highest rates of obesity (Yang et al. 2019). Also, globalization has significantly changed the behavior of populations, increasing the consumption of soft drinks and fast food (Alm et al. 2008, Canuto et al. 2020). Lack of activity and less exercise, the growing popularity of smartphones and social networks, media influences, and social changes in family structure have contributed to the increase in the number of overweight people worldwide (Alm et al. 2008, Canuto et al. 2020).

The relationship between obesity and caries experience has been recently studied, given that both conditions are etiologically associated with a sugar-rich diet (Banu et al. 2018). However, while the literature has pointed out an association between caries experience and overweight in adolescents (Lara-Capi et al. 2018, Jones Bell et al. 2018), our findings revealed no significant association between these variables, despite the high prevalence rates of caries observed in the study sample. The inconsistency in the findings may be explained by the fact that some studies have used indices that measure early carious lesions while the DMFT index, which was used herein, considers only the presence of cavitated carious lesions with dentin involvement. Moreover, despite the participants' low income, they had access to oral care through the healthcare system for the management of dental caries and other conditions (Shivakumar et al. 2018).

This study evaluated the relationship between normative and self-perceived malocclusion with obesity outcomes. Our findings showed that $94.6 \%$ of the sample had normative malocclusion. However, few adolescents $(8.4 \%)$ identified the need for treatment. The literature reports inconsistency between the subjective and normative malocclusion assessments (Cai et al. 2018). Most patterns of malocclusion are asymptomatic and hardly detectable if there is no aesthetic impairment (Dimberg et al. 2015). For this reason, including patient perception in oral health surveillance is as essential as a clinical assessment when making decisions regarding treatments (Banu et al. 2018).

The association between obesity and malocclusion is still poorly understood, especially when talking about the selfperception of the need for orthodontic treatment. A previous study, with a design similar to ours, did not find any significant relationship between these conditions (Giuca et al. 2015). However, a comparison between studies is not possible in this case because, in the study by Giuca et al. (2015), an orthodontist performed the subjective evaluation and not the individual himself, as recommended by the index (IOTN-AC).

The main findings of this study were that adolescents with self-perceived malocclusion were less likely to be obese, while those without self-perceived malocclusion were overweight. Evidence has shown that both malocclusion and obesity have a substantial psychosocial impact on an individual's life at a younger age (Banu et al. 2018, Lian et al. 2018, Sagar \& Gupta 2018). Currently, dissatisfaction with body image is heavily influenced by social media and the social context (Banu et al. 2018, Ferreira et al. 2021). During adolescence, esthetic changes of the smile and face can affect the individual's quality of 
life (Godinho et al. 2020), mainly because physical attractiveness plays an essential role in social relationships (Claudino \& Traebert 2013, Ferreira et al. 2021).

The study would further be strengthened if psychological characteristics such as self-esteem were incorporated. A longitudinal study design would also strengthen the study. The strength of this study was to include the self-perception of malocclusion in the evaluation. Also, adolescents were recruited from an economically vulnerable population, ensuring the homogeneity of the sample. The influence of possible confounding factors was low because the examiners were calibrated before evaluating the clinical data.

Finally, both malocclusion and obesity may have a significant impact on an individual's esthetic appearance (Vedovello et al. 2016, Xu et al. 2016). Nevertheless, the physical comorbidities resulting from obesity in childhood and adolescence may be even more incapacitating, producing a negative body image, in addition to mental health issues, such as depression, anxiety, eating disorder, stress, concern about body shape and low self-esteem (Banu et al. 2018, Sagar \& Gupta 2018). Overweight or obese school-age adolescents are more prone to suffer from chronic bullying due to their physical condition (Lian et al. 2018). Obese adolescents may also be subject of different types of victimization, not only of insults related to their physical appearance but also of threats, discrimination and social exclusion, which puts them in a state of global vulnerability (Pont et al. 2017). Therefore, public policies and health strategies should be implemented for effective prevention and management of obesity in childhood and adolescence, focusing not only on health-related parameters but also on the psychosocial aspect of the disease.

\section{Conclusion}

Obesity was not associated with dental caries and normative malocclusion. However, adolescents who perceive malocclusion are less likely to be obese, suggesting that obesity is associated with self-perception of malocclusion.

\section{References}

Abbass, M.M.S., AbuBakr, N., Radwan, I.A., Rady, D., El Moshy, S., Ramadan, M., Ahmed, A., \& Al Jawaldeh, A. (2019). The potential impact of age, gender, body mass index, socioeconomic status and dietary habits on the prevalence of dental caries among Egyptian adults: a cross-sectional study. F1000 Research 8, 243.

Al-Hussaini, A., Bashir, M.S., Khormi, M., AlTuraiki, M., Alkhamis, W., Alrajhi, M., \& Halal, T. (2019). Overweight and obesity among Saudi children and adolescents: Where do we stand today? Saudi Journal of Gastroenterology 25, 229-35.

Alm, A., Fahraeus, C., Wendt, L.K., Koch, G., Andersson-Gäre, B., \& Birkhed, D. (2008). Body adiposity status in teenagers and snacking habits in early childhood in relation to approximal caries at 15 years of age. International Journal Paediatric Dentistry 18, $189-96$.

Ashdown-Franks, G., Vancampfort, D., Firth, J., Veronese, N., Jackson, S.E., Smith, L., Stubbs, B., \& Koyanagi, A. (2019). Leisure-Time Sedentary Behavior and Obesity Among 116,762 Adolescents Aged 12-15 Years from 41 Low- and Middle-Income Countries. Obesity (Silver Spring) $27,830-6$.

Atlas of Human Development in Brazil. http:// https:// http://www.atlasbrasil.org.br/2013/ranking (accessed Nov 25, 2019).

Banu, A., Serban, C., Pricop, M., Urechescu, H., \& Vlaicu, B. (2018). Dental health between self-perception, clinical evaluation and body image dissatisfaction - a cross-sectional study in mixed dentition pre-pubertal children. BMC Oral Health 18, 74.

Blanco, M., Solano, S., Alcántara, A.I., Parks, M., Roman, F.J., \& Sepulveda, A.R. (2019). Psychological well-being and weight-related teasing in childhood obesity: a case-control study. Eating and Weight Disorders 25, 751-9.

Brook, P.H., \& Shaw, W.C. (1989). The development of an index of orthodontic priority. European Journal of Orthodontics 11, 309-20.

Cai, Y., Du, W., Lin, F., Ye, S., \& Ye, Y. (2018). Agreement of young adults and orthodontists on dental aesthetics \& influencing factors of self-perceived aesthetics. BMC Oral Health 18, 113.

Canuto, P.J., Medeiros, C.C.M., Vianna, R.P.T., Olinda, R.A., Palmeira, P.A., \& Carvalho, D.F. (2020). Associação entre o ambiente obesogênico e a ocorrência de sobrepeso/obesidade em adolescentes escolares. Research, Society and Development, 9, e229996984.

Claudino, D., \& Traebert, J. (2013). Malocclusion, dental aesthetic self-perception and quality of life in a 18 to 21 year-old population: a cross section study. BMC Oral Health 13,3. 
Consolação Soares, M.E., Ramos-Jorge, M.L., Alencar, B.M., Marques, L.S., Pereira, L.J., \& Ramos-Jorge, J. (2017). Factors associated with masticatory performance among preschool children. Clinical Oral Investigations 21, 159-66.

Dimberg, L., Arnrup, K., \& Bondemark, L. (2015). The impact of malocclusion on the quality of life among children and adolescents: a systematic review of quantitative studies. European Journal of Orthodontics 37, 238-47.

Ferreira, L.S., Rodrigues, T.C., Lima, V.S., Bezerra, A.N., Albuquerque, N.V., \& Pereira, C.P. (2021). Percepção da imagem corporal em adolescentes e a relação com seu estado nutricional. Research, Society and Development 10, e8710111484.

Gautam, S., \& Jeong, H.S. (2019). Childhood Obesity and Its Associated Factors among School Children in Udupi, Karnataka, India. Journal of Lifestyle Medicine 9, 27-35.

Giuca, M.R., Pasini, M., Caruso, S., Tecco, S., Necozione, S., \& Gatto, R. (2015). Index of orthodontic treatment need in obese adolescents. International Journal of Dentistry 2015, 876931.

Godinho, J., Gonçalves, R.P., \& Jardim, L. (2020). Contribution of facial components to the attractiveness of the smiling face in male and female patients: A cross-sectional correlation study. American Journal of Orthodontics and Dentofacial Orthopedics 157, 98-104.

Jones Bell, M., Zeiler, M., Herrero, R., Kuso, S., Nitsch, M., Etchemendy, E., Fonseca Baeza, S., Oliver, E., Adamcik, T., Karwautz, A., Wagner, G., Banos, R., Botella, C., Gorlich, D., Jacobi, C., \& Waldherr, K. (2018). Healthy Teens @ School: Evaluating and disseminating transdiagnostic preventive interventions for eating disorders and obesity for adolescents in school settings. Internet Interventions 16, 65-75.

Lara-Capi, C., Cagetti, M.G., Cocco, F., Lingstrom, P., Garcia-Godoy, F., \& Campus, G. (2018). Effect of body weight and behavioural factors on caries severity in Mexican rural and urban adolescents. International Dental Journal 68, 190-6.

Lavrador, M.S.F., Abbes, P.T., Escrivão, M.A.M.S., \& Taddei, J.A.A.C. (2010). Riscos cardiovasculares em adolescentes com diferentes graus de obesidade. Arquivos Brasileiros de Cardiologia 96, 205-11.

Lian, Q., Su, Q., Li, R., Elgar, F.J., Liu, Z., \& Zheng, D. (2018). The association between chronic bullying victimization with weight status and body selfimage: a cross-national study in 39 countries. PeerJ 6, e4330.

Markovic, D., Ristic-Medic, D., Vunic, V., Mitrovic, G., Nikolic Ivosevic, J., Peric, T., \& Karadzic, I. (2015). Association between being overweight and oral health in Serbian schoolchildren. International Journal of Paedriatric Dentistry 25, 409-17.

Pont, S.J., Puhl, R., Cook, S.R. \& Slusser, W. (2017). Stigma Experienced by Children and Adolescents with Obesity. Pediatrics 140, e20173034.

Rando-Meirelles, M.P.M., Sousa, M.L.R., Vale, G.C., Lages, V.A., Vásquez, P.P., Jimenez, P., Villena, R.S., \& Alvarez-Paucar, M.A. (2019). Oral health and obesity in the SAYCARE study: reliability and internal validity of diagnostic methods. Obesity Science \& Practice 5, 59-67.

Sagar, R., \& Gupta, T. (2018). Psychological Aspects of Obesity in Children and Adolescents. Indian Journal of Pediatrics 85, 554-9.

Shivakumar, S., Srivastava, A., \& Shivakumar, G. (2018). Body Mass Index and Dental Caries: A Systematic Review. International Journal of Clinical Pediatric Dentistry 11, 228-32.

Vedovello, S.A., Ambrosano, G.M., Pereira, A.C., Valdrighi, H.C., Filho, M.V., \& Meneghim, M.C. (2016). Association between malocclusion and the contextual factors of quality of life and socioeconomic status. American Journal of Orthodontics and Dentofacial Orthopedics 150, 58-63.

World Health Organization. (1997) Oral Health Surveys. Basic methods. 4th edition. Geneva: World Health Organization.

World Health Organization. (2009). WHO AnthroPlus for Personal Computers Manual: Software for Assessing Growth of the World's Children and Adolescents. Geneva: WHO.

Yang, L., Bovet, P., Ma, C., Zhao, M., Liang, Y., \& Xi, B. (2019). Prevalence of underweight and overweight among young adolescents aged $12-15$ years in 58 low-income and middle-income countries. Pediatric Obesity 14, e12468.

Xu, J., Hardy, L.L., Guo, C.Z., \& Garnett, S.P. (2018). The trends and prevalence of obesity and morbid obesity among Australian school-aged children, 1985-2014. Journal of Paediatrics and Child Health 54, 907-12.

Zhou, Y., Zhang, Q., Wang, T., Zhang, Y., \& Xu, B. (2017). Prevalence of overweight and obesity in Chinese children and adolescents from 2015. Annals of Human Biology 44, 642-3. 